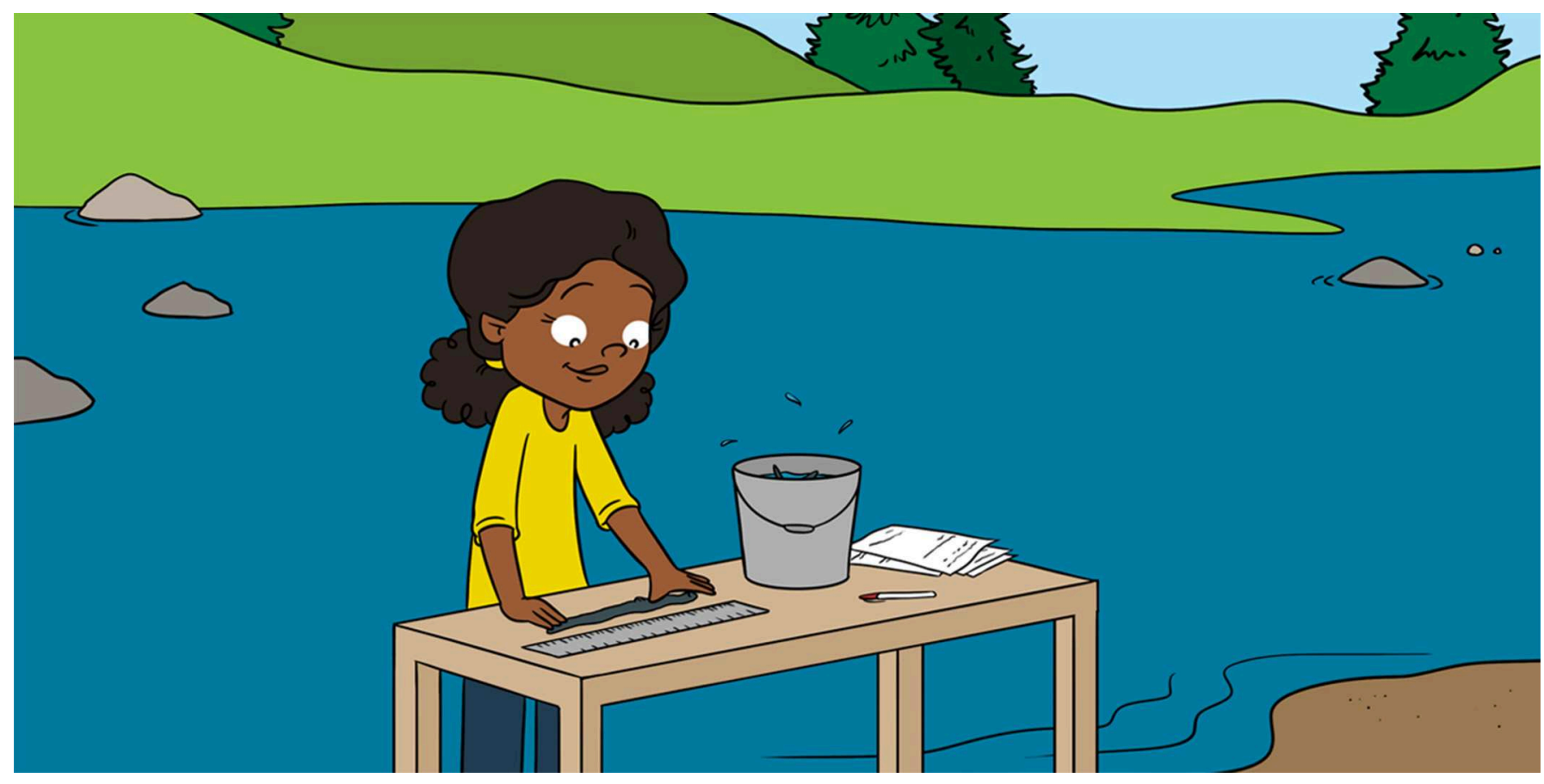

\title{
DISCOVERING THE MYSTERIOUS SPAWNING HABITS OF THE THREATENED COWICHAN LAKE LAMPREY
}

\section{Joy Wade ${ }^{1 *}$, Lindsay Dealy ${ }^{2}$ and Sean MacConnachie ${ }^{2}$ \\ ${ }^{1}$ Fundy Aqua Services Inc., Nanoose Bay, BC, Canada \\ ${ }^{2}$ Fisheries and Oceans Canada, Pacific Biological Station, Nanaimo, BC, Canada}

YOUNG REVIEWER:

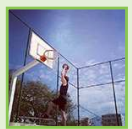

GUSTAVO

AGE: 14
The Cowichan Lake lamprey, a parasitic fish discovered in the 1980s, is listed as a threatened species under Canada's Species at Risk Act. Since its discovery, there have been very few studies to understand the biology and habitat needs of the animal. This is partially because Cowichan Lake lamprey are hard to study; they are small, hide well, and are mostly active at night. Because they are a protected species, we still must make decisions to help ensure their survival. We know very little about the animal, but we have started conducting studies to unravel the mystery of the Cowichan Lake lamprey. This study describes one such discovery. For the first time, we have observed spawning and nest building. We have also begun to answer questions about what kind habitat the lamprey needs for spawning. Building on this discovery, we will keep working to answer other questions that will aid the conservation of the Cowichan Lake lamprey and its habitat. 
Figure 1

Drawing of a typical lamprey ammocoete (larvae) with its body in the sediment and its mouth sticking out above the sediment to feed on food as it floats by in the water (illustration credit, C. Stephen).

\section{AMMOCOETE}

The larval form of a lamprey (rhymes with "feet").

\section{PARASITIC}

In lamprey, this means a lamprey which feeds off of the live body of another animal, usually a fish.

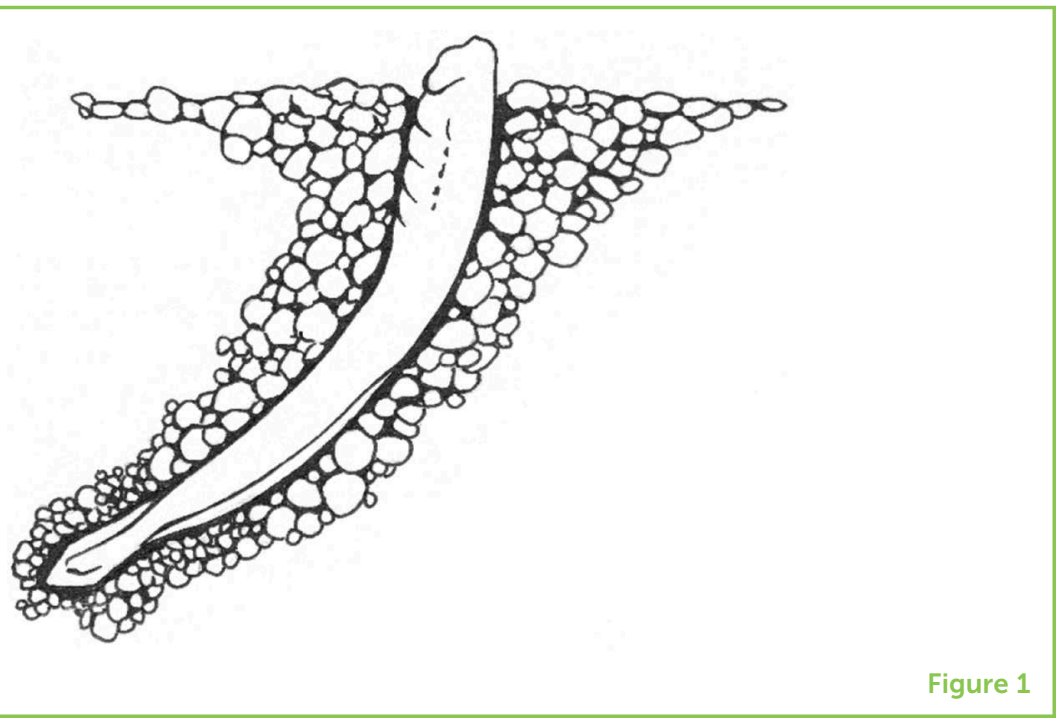

\section{WHAT IS A LAMPREY?}

Lamprey are an amazing group of ancient fishes which first appeared on the planet around 360 million years ago [1], millions of years before dinosaurs appeared on earth. They are a jawless, boneless, scaleless fish, with a long, slender, eel-shaped body.

Lampreys have a unique life cycle. They spend most of their lives as ammocoetes, the word for larval lamprey. Ammocoetes are blind and spend most of their time in the sediment with their mouths sticking out, waiting for decomposing plant and animal bits to float by so they can eat them (Figure 1). Some species of lamprey are ammocoetes for 6 years before finishing their development and becoming adults!

Once they are adults, the big differences between lamprey species are more obvious. Lamprey can be either: (1) freshwater non-parasitic, (2) freshwater parasitic, or (3) anadromous parasitic. Freshwater non-parasitic lampreys spend their lives in streams and rivers where they feed on decomposing pieces of plants and animals. Freshwater parasitic lampreys spend their whole lives in freshwater as well. As adults, they suck onto the sides of other fish species, like trout, and use their tongues and teeth to grate skin tissue and blood from their prey. Anadromous parasitic lampreys grow and develop in freshwater before migrating to the sea, where they feed parasitically on ocean fish, like sharks, salmon, and pollock, before returning to freshwater to spawn. Because some species are parasitic and feed on blood and skin tissue, some lampreys have been called aquatic vampires!

\section{COWICHAN LAKE LAMPREY: A UNIQUE SPECIES}

On the west coast of Canada on Vancouver Island in British Columbia, there is a species of freshwater parasitic lamprey found nowhere else 
Figure 2

Drawing of the underside of a Cowichan Lake lamprey showing the teeth and rasping tongue (left) and a Cowichan Lake lamprey parasitizing a trout (right) (illustration credit, C. Stephen).

\section{METAMORPHOSIS}

In lamprey, the dramatic physical change from an ammocoete (larval form) to an adult form. Metamorphosis takes place over several months where they develops eyes, teeth and a digestive system which can absorb nutrients from adult food.

\section{SPAWNING}

The release of eggs into the water.
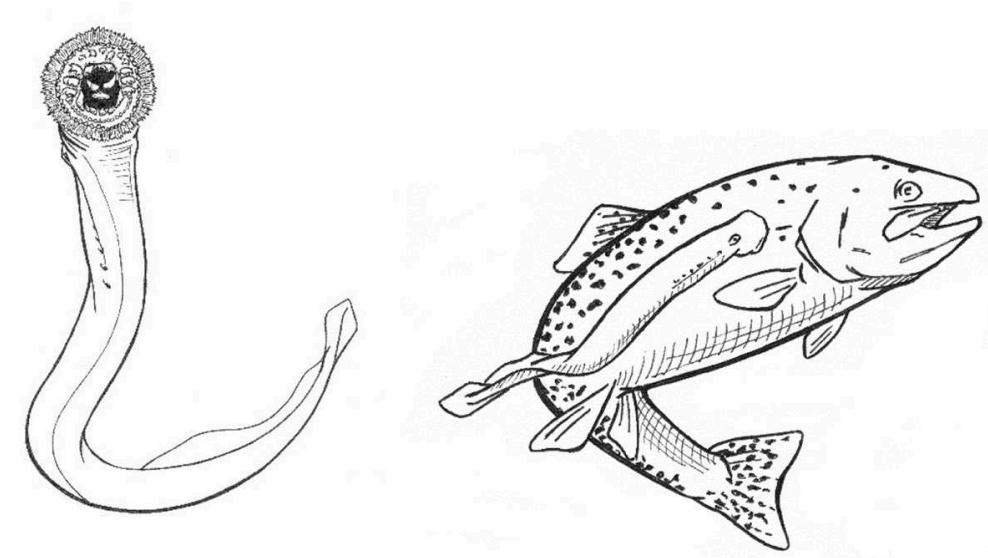

Figure 2

in the world, the Cowichan Lake lamprey [2]. This fish spends its whole life in Cowichan and Mesachie lakes. This water system is managed by a weir on Cowichan Lake. The dam holds water in Cowichan Lake so that it can be let out into the Cowichan River when the water supply in the river is low. People use the water from the river for drinking, sewage treatment, businesses, and recreation. It is also important to have water in Cowichan River to support all aquatic plant and animal species that live there.

Compared to some other lamprey species which grow as long as $120 \mathrm{~cm}$ long, Cowichan Lake lamprey are small, a total length of about $27 \mathrm{~cm}$. Like all lamprey species, Cowichan Lake lamprey spend most of its life as an ammocoete, but then undergoes metamorphosis. During metamorphosis, an ammocoete changes into an adult with functional eyes, mouth, and digestive system. After metamorphosis, the Cowichan Lake lamprey is a parasitic adult and cutthroat trout are one of their favorite foods. The Cowichan Lake lamprey sucks onto trout with its mouth, called an oral disc, and uses its sharp teeth and tongue to grind at the trout's skin and tissues to fuel their growing body (Figure 2). If you go fishing for cutthroat trout in Cowichan or Mesachie lakes, you will find circles on the sides of the fish, where lamprey have fed!

Because this species is unique and found nowhere else in the world, they are protected by the government of Canada. This means that as citizens, scientists and governments we have an obligation to protect both the lamprey and their habitat. In order to do so, we need to be able to make smart decisions. There is a lot we do not know about Cowichan Lake lamprey like how long they live, how much they need to eat, and what kinds of habitats they need. Most importantly, we need to know when and where they spawn. The purpose of our study was to answer this question and, if we were lucky, maybe see them spawning! 


\section{THE HUNT FOR SPAWNING LAMPREY}

We knew that Cowichan Lake lamprey spawned in the summer [3], but not exactly when or where so we set up an experiment to try to answer these questions. Based on results from other studies, we thought they might spawn on the sandbars where rivers emptied into the lakes [2]. So, we made traps and put them on the sandbars. The idea was that the lamprey would swim from the deep water of the lake up over the sandbar and encounter the traps. The traps were made out of wire mesh with a small opening on each end. Once the lamprey were in, they could not figure out how to get out.

We checked the traps each day for over 2 weeks and by the end of the experiment we caught a total of 31 lamprey. We carefully removed each fish from the trap and put it into a bucket of water where it could swim around until we took our measurements. To take the measurements, we had to put the fish to sleep so that they were calm. We dissolved an anesthetic in a bucket of water and put the fish in the water. Once asleep, we removed them from the water and carefully placed them on a ruler to measure the total length from snout to tail and took a picture. We worked quickly and carefully to minimize the amount of handling because fish have a protective mucous coating on their skin that helps prevent injury and disease. When we were done we put the lamprey into a bucket of freshwater so they could recover from the anesthesia, then returned them to the wild. The whole sampling took only a few minutes. We worked quickly and carefully to minimize harm to the animals, something particularly important when working with rare species.

When we were examining the lamprey, we discovered that we could tell the difference between males and females just by looking, in most fish species you cannot! In animals in spawning condition, the females had fleshy folds around their gonadopore and an upturned tail, the males did not. A gonadopore is where the unfertilized eggs exit the body for a female and where the milt (or sperm) exits the body for males.

During the study, for the first time ever, we were lucky to find three lamprey nests with lamprey actively spawning [4]! We were lucky to capture them spawning on Video. Cowichan Lake lamprey are amazing in that they use their oral discs to move small pebbles and rocks around to make nests. The nests do not look like much, just shallow depressions in the substrate, not much deeper than a footprint. But unlike a footprint, there is great care and attention paid in making these nests. Typically, males start nest making and then females join in. When it comes time to spawn, they may do so in pairs, one male and one female, or in groups of many lamprey all together, a ball of spawning fish. Males use their oral disc to suck onto the female's head and then he coils his body around hers (Figure 3). They both wriggle back and forth, and the male uses his body to squeeze the 
Figure 3

Drawing of two lamprey spawning (illustration by $\mathrm{C}$. Stephen). unfertilized eggs out of the female. They may do this a few times, moving a few rocks around the nest in between squeezings. When they are finished, the two swim off their separate ways. Although we do not know for sure, we presume that Cowichan Lake lamprey are like other lamprey species and they spawn only once before dying.

\section{WHAT DID WE LEARN?}

We discovered that the Cowichan Lake lamprey use sand bars at the mouths of rivers to spawn and incubate their eggs. We know from past studies that both very young $(1.5 \mathrm{~cm}$ total length) and much older (14 cm total length) ammocoetes can be found in and around these areas [5]. We also know that the ammocoete life stage is very long, many years. If it takes many years to reach a maximum length of about $27 \mathrm{~cm}, \mathrm{a} 14 \mathrm{~cm}$ ammocoete is probably several years old. This leads us to conclude that the areas where spawning occurs are important for ammocoete rearing as well.

We also learned that Cowichan Lake lamprey spawn in pairs as well as in groups. We saw two different pairs of lamprey spawning in two different nests, and in one nest a group of four were spawning. We have also started collecting data on the sizes of rocks and pebbles they use to build nests. This is important to know because we want to ensure that the lamprey have access to what they need to build their nests. In some places around Cowichan Lake, people are removing rocks or adding sand to make beaches. If we know what size rocks and pebbles are needed for nest building, we can make sure people are not changing the habitat and affecting spawning.

\section{HOW CAN THIS INFORMATION MAKE THE COWICHAN LAMPREY'S LIFE BETTER?}

Now that we know where Cowichan Lake lamprey spawn, we have provided this information to local governments so they can include 
the needs of lamprey in the management of the weir. As a result of climate change, there have been more summertime droughts and less rain and snow in the winter in this region. This means there will be less water stored in Cowichan Lake to use in the hot dry summer, when Cowichan Lake lamprey spawn. If there is less water stored, the areas where they spawn will have very little water or may be entirely dry. If the spawning area is dry, the fish cannot spawn. If the fish cannot spawn there will be no new lamprey.

In this study, we also learned the importance of water conservation. The Cowichan Lake area may not have as much precipitation as it used to, but we can all do our part to conserve water for all species, including the Cowichan Lake lamprey.

So, why bother helping a parasitic blood-sucking fish? For two reasons. First, lamprey are food for many other species in the ecosystem, and, increase the complexity of our amazing aquatic environment. Second, they are fascinating creatures in their own right!

\section{ORIGINAL SOURCE ARTICLE}

Wade, J., Dealy, L., and MacConnachie, S. 2018. First record of nest building, spawning and sexual dimorphism in the threatened Cowichan Lake (Vancouver) lamprey (Entosphenus macrostomus). Endanger. Species Res. 35:39-45. doi: 10.3354/esr00872

\section{REFERENCES}

1. Gess, R. W., Coates, M. I., and Rubidge, B. S. 2006. A lamprey from the Devonian period of South Africa. Nature 443:981-4. doi: 10.1038/nature05150

2. Beamish, R. J., and Wade, J. 2008. Critical habitat and the conservation ecology of the freshwater parasitic lamprey, Lampetra macrostoma. Can. Field Nat. 122:327-37. doi: 10.22621/cfn.v122i4.640

3. Beamish, R. J. 1982. Lampetra macrostoma, a new species of freshwater parasitic lamprey from the west coast of Canada. Can. J. Fish. Aquat. Sci. 39:736-47.

4. Wade, J., Dealy, L., and MacConnachie, S. 2018. First record of nest building, spawning and sexual dimorphism in the threatened Cowichan Lake (Vancouver) lamprey (Entosphenus macrostomus). Endanger. Species Res. 35:39-45. doi: 10.3354 /esr00872

5. Wade, J., and MacConnachie, S. 2016. Cowichan Lake lamprey (Entosphenus macrostomus) ammocoete habitat survey 2012. Can. Manuscr. Rep. Fish. Aquat. Sci. 3088:iv, 15p.

SUBMITTED: 17 June 2019; ACCEPTED: 04 October 2019; PUBLISHED ONLINE: 18 October 2019. 
EDITED BY: Pedro Morais, Centre of Marine Sciences, University of Algarve, Portugal

CITATION: Wade J, Dealy L and MacConnachie S (2019) Discovering the Mysterious Spawning Habits of the Threatened Cowichan Lake lamprey. Front. Young Minds 7:125. doi: 10.3389/frym.2019.00125

CONFLICT OF INTEREST: The authors declare that the research was conducted in the absence of any commercial or financial relationships that could be construed as a potential conflict of interest.

COPYRIGHT @ 2019 Wade, Dealy and MacConnachie. This is an open-access article distributed under the terms of the Creative Commons Attribution License (CC BY). The use, distribution or reproduction in other forums is permitted, provided the original author(s) and the copyright owner(s) are credited and that the original publication in this journal is cited, in accordance with accepted academic practice. No use, distribution or reproduction is permitted which does not comply with these terms.

\section{YOUNG REVIEWER}

\section{GUSTAVO, AGE: 14}

$\mathrm{Hi}$, I am Gustavo, from Portugal. I love to swim, surf, play basketball, and read manga books. My mom is a marine biologist and I want to become a marine biologist myself!

\section{AUTHORS}

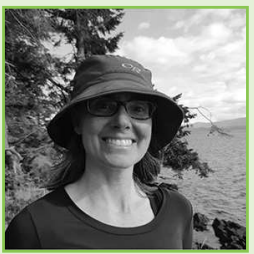

\section{JOY WADE}

Joy Wade is a research biologist whose scientific pursuits include building ecosystem resilience for better decision making in a rapidly changing world. Her interests focus on aquatic biology and conservation of species and habitat. *joywadefundyaqua@gmail.com
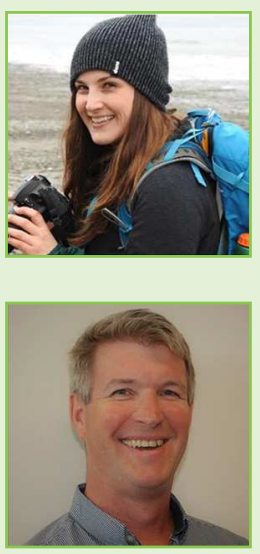

\section{LINDSAY DEALY}

Lindsay Dealy is a field technician with Fisheries and Oceans Canada who surveys a plethora of marine species, including juvenile salmon, eulachon, prawns, rockfish, and local invasive species, as well as freshwater fish like the Cowichan Lake lamprey.

\section{SEAN MACCONNACHIE}

Sean MacConnachie is a research biologist who has worked for Fisheries and Oceans Canada for 20 years, primarily focused on species at risk, with special emphasis on lamprey, freshwater mussels and marine mammals. 